both executive and corresponding members who have died since 1938 will be welcomed. Prof. Brunet further wishes to receive from members copies of books and brochures published by them since 1939, together with a note both of their own activities and that of their national group during the intervening period. Obituary notices of those who have died, together with photographs, are also desired.

\section{Mineral Resources and Exploration}

In his presidential address delivered on May 16 before the Institution of Mining and Metallurgy, Mr. G. F. Laycegk reviewed the general position as regards the frepable world resources of some of the more impwant metals, the prospects of finding further supplies and the methods employed in the sfargh tor new ore-bodies. For many years past few depfieries of important deposits have been made, a part from gold and iron. In Canada, for example, 84 per cent of the 1942 production was obtained from mineral areas discovered before 1920 , and only 5 per cent from those discovered since 1930. Except in the U.S.S.R., the position is probably much worse in most other countries. Obviously, to a very large extent we are to-day living on our mineral capital. While it is clear that the era of surface prospecting has entered the phase of diminishing returns, there is every probability that many valuable ore-deposits, which do not outcrop or even closely approach the surface, still remain to be discovered. Mr. Laycock emphasizes the following suggestions: (1) Intensive research should be directed towards the development of new or improved methods of geophysical exploration with a view to the elimination of the uncertainties and weaknesses of existing methods. (2) Operating companies must be officially encouraged, for example, by tax reliefs, to carry out intensive prospecting for new sources of ore in and around existing workings by means of geological, geophysical and diamonddrilling methods. (3) Exploration companies should be formed to investigate potentially promising virgin areas where old-fashioned prospecting methods are useless by themselves; prospecting rights must be granted over wide areas, and the very considerable expenses of such large-scale operations should be allowable for taxation purposes as deductions against any future profits. Mr. Layeock predicts that with such stimulation and governmental assistance the present unsatisfactory position is likely to be greatly improved by the discovery of important concealed deposits.

\footnotetext{
Chemical Engineering as a Profession

THERE is a very marked expansion at the present moment of those industries which are mainly concerned with some chemical process for their develop. ment. There is so great a demand for chemical engineers that the Institution of Chemical Engineers, in conjunction with the Institute of Petroleum, the Association of British Chemical Manufacturers and the British Chemical Plant Manufacturers Association, addressed a memorandum to the Government, directing attention to this remarkable development, and at the same time emphasized the very great shortage of trained chemical engineers in Great Britain compared, for example, with that existing in the United States. The number of students each year studying for a degree in chemical engineering
}

is at present about forty in Britain, compared with three thousand in the United States. To meet the situation, the Government is proposing to establish courses in chemical engineering for those who already have a chemistry, physics or engineering degree, as a short-term policy in order to train chemical engineers to meet this demand, which at the present moment is more active on the plant-manufacturing side, owing to the fact that many proposed improvements and developments have had to be postponed until after the War. While, therefore, at the moment there is a special demand for men to design and erect this equipment, there are also big requirements for chemical engineers in the industries using plant. The fourth year of the degree course recommended by the Institution of Chemical Engineers roughly corresponds to the post-graduate courses now being organised. The exact training which the students receive will depend, of course, to some extent on their previous knowledge, and will be designed to enable them to approach the chemical engineering course proper with sufficient background in the general principles of chemistry and mechanical and electrical engineering.

\section{Recent Earthquakes}

DURING May 1946 several strong earthquakes occurred in various parts of the earth. Many of these had their epicentres under the sea and thus fortunately did little materal damage. These include the shocks of May of outh-east of New Guinea; May 8, west of Surnalra; May 9, Gulf of California; and May 15 peff coast of Southern Mexico (United States Coast and Geodetic Survey). The shock of May 21 did damage on Martinique, West Indies. Its epicentre has been determined on the basis of instrumental reports from eleven observatories by the United States Coast and Geodetic Survey as being lat. $14 \cdot 2^{\circ} \mathrm{N}$., long. $60 \cdot 8^{\circ} \mathrm{W}$, and origin time $09 \mathrm{~h}$. $16 \cdot 6 \mathrm{~m}$. G.M.T. Two strong shocks at $02 \cdot 30 \mathrm{hr}$. and $04.40 \mathrm{hr}$. on May 30 with epicentre in Canton Valais, Switzerland, did some damage to a church and houses at Bex. Houses were badly shaken at Berne, but no damage was done. In addition to the shocks of May 3 and 8, Mr. E. W. Pollard in the Isle of Wight recorded a smaller distant shock on May 11 .

Early on Saturday, June 1, a severe earthquake occurred in the region of Mush, eastern Anatolia, Turkey, about 480 miles south-east of Ankara. Severe damage is reported to include 215 houses destroyed; 590 people are said to have been killed and about 100 injured.

\section{Films in Microbiology and Protistology}

Finms made under the direction of Dr. Comandon by the Departement de Cinémicrographie, Institut Pasteup, Garches, S. et O., will be brought to Great Britoin shortly by M. Pierre de Fonbrune. They include those reviewed in the Lancet (Jan. 11, 1946, p. 111) and in the British Medical Bulletin (4, No. 1, 72 ; 1946); also films on Amoba verrucosa and Lankesterella and on mitosis. They are silent films on $35 \mathrm{~mm}$. stock with captions in French. A selection of these films will be shown in London by the British Council on July 15, at 5 p.m. A limited number of seats is available and will be allotted in rotation on application to the British Council, 3 Hanover Street, London, W.1. 